\title{
Echinoderm Antimicrobial Peptides to Contrast Human Pathogens
}

\author{
Domenico Schillaci ${ }^{1 *}$ and Vincenzo Arizza ${ }^{1,2}$ \\ ${ }^{1}$ Dip. STEBICEF, Università degli Studi di Palermo, Via Archirafi 18, - 90123 Palermo, Italy \\ ${ }^{2}$ Istituto Euromediterraneo di Scienza e Biotecnologia - 90139 Palermo, Italy
}

\begin{abstract}
Increased attention has been focused in marine invertebrates as a source of bioactive molecules for biomedical applications. Many bioactive molecules are part of the innate immune system. Some more recently isolated compounds, mainly from sea urchin and sea cucumber are antimicrobial peptides (AMP) active against Gram positive, Gram negative and fungi. In this review we described the most recent studies on AMP isolated from echinoderms. The AMP are little peptides < $10 \mathrm{kDa}$ with cationic charge and amphipathic structure. Recently, it was demonstrated that in the coelomocyte lysates of Paracentrotus. lividus and Holothuria tubulosa AMP are present with activity against staphylococcal and Pseudomonas aeruginosa antibiofilm. The data show the great potential of application of AMPs in biotechnology for developing novel therapeutic agents and as complements to conventional antibiotic therapy to combat the multi - resistant bacterial strains.
\end{abstract}

Keywords: Antimicrobial peptides; Therapeutic agents; Antibiotic therapy

\section{Introduction}

Echinoderms are an ancient group of marine invertebrates that live in both the intertidal and deep sea benthos composed approximately by 7000 extant species that including sea stars (asteroids), sea urchin (echinoids), sea cucumbers (holothurians), brittle stars (ophiuroids) and sea lilies (crinoids). Because, many species live in near the coastal or estuaries waters overloaded with infectious organisms, such as virus, bacteria, fungi and other parasites, they are exposed to a broad variety of challenges to their self-integrity. To survive in high impact environments have evolved efficient defense strategies.

Echinoderms, similarly to other invertebrates, do not possess a specific immune response. Therefore they ensure the protection of their organism and its homeostasis using natural immunity responses. Among the innate immune system humoral components, antimicrobial peptides (AMPs) are the major defense molecules of innate immunity and are widespread in nature. Indeed they are produced by living organisms of all kingdoms throughout the bacteria and animal including fungi and plants [1-8]. Currently, more than 4000 peptides have been isolated and characterized from tissues and organisms and have been listed in the main databases (Table 1), or in journal publications [9].

Usually, AMPs have small molecular weight with no more 100 amino acids and a molecular weight $<10 \mathrm{kDa}$. They differ considerably in amino acid sequence and structural conformation and most of them are positively charged showing a net positive charge of +2 to +9 due to an excess number of acidic, with a hydrophobic face opposite to hydrophilic one. These chemo-physical characteristics allow these peptides to be soluble in water but react simultaneously with the hydrophobic layer of microbial membranes.

The mode of action of AMPs has rarely been addressed and is therefore not yet understood [10]. It is generally agreed that the AMPs are initially recruited on the microbial surface through electrostatic interaction between cationic portion of the peptides and the negativelycharged microbial cell walls and/or membranes. When, the peptide/ lipid ratio increases, the peptides start forming multimers or selfassociating on top of the membrane. When the peptides reach a high concentration they orientate perpendicularly and insert into the bilayer, thereby interfering with membrane integrity. The microorganisms are then destroyed or via membrane destabilization and/or pore formation $[10,11]$ or through interference with several essential metabolic functions, such as protein, nucleic acid and cell wall syntheses acting on nucleic acids and/or enzymatic proteins, leading to bacterial cell death [10-14]. Moreover, it appears that many AMPs may be multifunctional microbicides, acting simultaneously at the cell membrane and internal sites [11].

In invertebrates, AMPs are ubiquitous distributed, found especially in hemolymph and in tissues such as epidermis, gut and respiratory organs where exposure to pathogenic microorganisms is most likely, expressed constitutively or in response to a pathogen stimulus. The AMPs defend the organisms not only through their ability to kill bacteria, but it was shown that they have antitumor effects, mitogenic activity and, most importantly, participate in immunoregulatory mechanisms by modulating signal transduction and cytokine production and/or release $[3,11,12,15-22]$.

The purpose of this mini-review will be to present the most recent data on antimicrobial peptides isolated and characterized in the phylum Echinoderms. In particular we will focus on their structure, biological functions and in their potential application as antimicrobial and antibiofilm agents to contrast human pathogens.

\section{Antimicrobial Peptides in Echinoderms}

Truong et al. [23] discovered, for the first time in echinoderm, the presence of AMPs in the coleomic fluid of the sea cucumber Cucumaria frondosa. Since 2001 the number of molecules has increased steadily. They can be mainly found in coelomocytes, the effector cells of immunity, and occasionally in coelomic fluid. In some cases have been also found in the gastrointestinal organs, in the eggs and in the body wall [24]. Many of AMPs are derived from larger proteins that could be enzymatically digested and produce active fragments. This has been demonstrated by Ghanbari et al. [25]. In fact, by digesting the tissues of sea cucumber Actinopyga lecanora with bromelain, peptides with inhibitory activities against respectively Pseudomonas sp., P. aeruginosa and $E$. coli were obtained and one papain digested fraction showed

*Corresponding author: Domenico Schillaci, Dip. STEBICEF, Università degl Studi di Palermo, Via Archirafi 18, - 90123 Palermo, Italy, Tel: +3909123891914; E-mail: domenico.schillaci@unipa.it

Received May 18, 2013; Accepted June 18, 2013; Published June 24, 2013

Citation: Schillaci D, Arizza V (2013) Echinoderm Antimicrobial Peptides to Contrast Human Pathogens. Nat Prod Chem Res 1: 109. doi:10.4172/npcr.1000109

Copyright: @ 2013 Schillaci D, et al. This is an open-access article distributed under the terms of the Creative Commons Attribution License, which permits unrestricted use, distribution, and reproduction in any medium, provided the original author and source are credited. 
antibacterial activity against $S$. aureus. Aleshina et al. [26], found that among the AMPs isolated in starfish Asterias rubens, two peptides were part of histone molecule H2A. Maltseva and co-workers also found that two other peptides were fragments of actin, while one peptide was a fragment of filamin A.

A fraction at low molecular weight $(<5 \mathrm{kDa})$ acid extract of Paracentrotus livudus coelomocytes contained an antimicrobial peptide active against Gram positive and Gram negative pathogens [27]. The peptide belonging to the segment (9-19) of a $\beta$-thymosin, a ubiquitous peptide that possesses several biological effects as such as induction of metalloproteinases, chemotaxis, angiogenesis and inhibition of inflammation [28]. The $\beta$ thymosins are a family of highly conserved polar 5 -kDa peptides originally thought to be thymic hormones. They are present at high concentrations in almost every cell from vertebrate phyla and have several biological functions due to direct and indirect effects on the actin cytoskeleton. $\beta$-Thymosin is also described as one of the AMP of platelets from animals and human beings [29]. There is little information about the function of thymosins in invertebrates, but their presence has been reported in marine invertebrates [30,31] and in insects where they are up regulated by microbial infections [32].

\section{Cystein Rich Antimicrobial Peptides}

Antimicrobial peptides in echinoderms are generally heterogeneous molecules and until a few years ago it was not possible to sort them into classes of molecules. Li [33] discovered in Strongylocentrotus droebachiensis two AMPs called Strongylocins (Table 2). The strongylocin peptides are members of the cysteine-rich AMP family, which have six cysteines with three disulfide bonds involved in peptide conformation, stabilization and resistance to proteases [34] and which are crucial for the antimicrobial activity $[35,36]$. The strongylocins show different pattern with the other members of the family suggesting that the change in molecular conformation could allow resisting to the proteolysis within the coelomocytes and in the coelomic fluid. Homologues are also present in the sister species $S$. purpuratus, called SpStrongylocins [37]. Furthermore, in S. purpuratus Li et al. [38] have found other two AMPs called centriocins with a potent activity against
Gram-positive and Gram-negative bacteria. These are heterodimeric molecules consisting of two subunits, a heavy chain of (30 amino acids) and a light chain (12 amino acids) linked by an intramolecular disulfide bridge. Novel synthetic peptides sequentially derived from the AMP centrocin 1, were recently tested for their anti-infective and antiinflammatory effects [39].

\section{Antimicrobial Biofilm Peptides}

The biofilm is a complex community of microbial cells that are associated with a surface and enclosed in a self-produced biopolymer matrix (Figure 1). The capability to organise a biofilm community is present in almost all Gram-negative and Gram positive bacteria and several of them can be highly pathogenic for animals and human beings. The pathogenic role of bacterial biofilms is well known in human health, because they are responsible for chronic infections and device and biomaterial associated infections [40-42].

Antibiotics can be efficacious against planktonic (free living) pathogens but are quite often poorly effective against the bacteria organized in community which can increase antibiotic resistance by up to 1000 fold [43]. Biofilm structured bacteria develop a multifactorial mechanism of resistance to antibiotics, but the most important factor of tolerance is due to the slow growth and low metabolic activity of bacterial cells in the internal layer of community, so they are intrinsically resistant to conventional antibiotics which target dividing and metabolically active cells.

On the contrary, the prevalent mechanism of action of AMPs is due to their ability to permeabilize and/or to form pores within the cytoplasmic membranes, so they have a high potential to act also on slow-growing or even non growing bacteria that exhibit a reduced susceptibility to many antibiotics and represent a reservoir for recurrent biofilm infections. The AMPs also have a high potential for inhibiting biofilm formation, in fact, they can act at several stages of biofilm formation and with different mechanisms of action: they may minimize initial adhesion of microbial cells to abiotic surfaces by altering the adhesive features of abiotic surfaces, or by binding to

\begin{tabular}{|l|l|l|l|}
\hline \multicolumn{1}{|c|}{ Name } & \multicolumn{1}{c|}{$\begin{array}{c}\text { Origin } \\
\text { n. of listed antimicrobial } \\
\text { peptides }\end{array}$} & \multicolumn{1}{c|}{ Web address } \\
\hline CAMP & 4020 & Prokaryotes and eukaryotes & http://www.bicnirrh.res.in/antimicrobial/ \\
\hline DAMPD & 1232 & Prokaryotes and eukaryotes & http://apps.sanbi.ac.za/dampd/ \\
\hline APD & 2221 & Prokaryotes and eukaryotes & http://aps.unmc.edu/AP/main.php \\
\hline AMSDB & 895 & Eukaryotic & http://www.bbcm.units.it/ tossi/amsdb.html \\
\hline BACTIBASE & 177 & Bacteriocin & http://bactibase.pfba-lab-tun.org/statistics.php \\
\hline DEFENSINS KNOWLEDGEBASE & 363 & Defensin & http://defensins.bii.a-star.edu.sg/ \\
\hline PhytAMP & 271 & Plant & http://phytamp.pfba-lab-tun.org/main.php \\
\hline
\end{tabular}

Table 1: List of Peptides which are isolated and characterized from tissues and organisms.

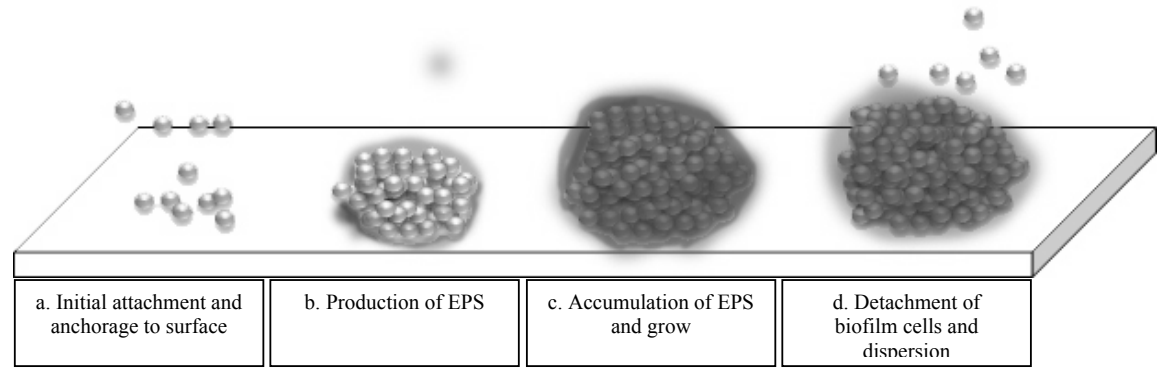

Figure 1: The cycle of biofilm. a: attachment of planktonic cells to a surface. b: Recruitment of other planktonic cells and production of EPS. c: growth and development of biofilm through cell division and recruitment. d: dispersion of bacteria from biofilm. 
Citation: Schillaci D, Arizza V (2013) Echinoderm Antimicrobial Peptides to Contrast Human Pathogens. Nat Prod Chem Res 1: 109. doi:10.4172/ npcr.1000109

Page 3 of 4

\begin{tabular}{|c|c|c|c|c|c|}
\hline Class and genus & AMPs & Molecular mass (kDa) & Target & Charge & Reference \\
\hline \multicolumn{6}{|l|}{ Asteroidea } \\
\hline Asterias rubens & & $\sim 20$ & $\begin{array}{l}\text { Gram (-) } \\
\text { Gram (+) }\end{array}$ & n.d. & [24] \\
\hline \multicolumn{6}{|l|}{ Echinoidea } \\
\hline \multirow{2}{*}{ Strongylocentrotus droebachiensis } & Strongylocins 1 & 5.6 & \multirow{2}{*}{$\begin{array}{l}\text { Gram (-) } \\
\text { Gram (+) }\end{array}$} & cationic & \multirow{2}{*}{ [33] } \\
\hline & Strongylocins 2 & 5.8 & & cationic & \\
\hline \multirow{2}{*}{ Strongylocentrotus purpuratus } & SpStrongylocins 1 & 5.6 & \multirow{2}{*}{$\begin{array}{c}\text { Gram (-) } \\
\text { Gram (+) }\end{array}$} & cationic & \multirow{2}{*}{ [37] } \\
\hline & SpStrongylocins 2 & 6.0 & & cationic & \\
\hline \multirow{2}{*}{ Strongylocentrotus droebachiensis } & Centrocins 1 & 4.4 & \multirow{2}{*}{$\begin{array}{l}\text { Fungus } \\
\text { Gram (+) } \\
\text { Gram (-) }\end{array}$} & \multirow{2}{*}{ cationic } & \multirow{2}{*}[38]{} \\
\hline & Centrocins 2 & 4.5 & & & \\
\hline Paracentrotus lividus & Paracentrin & 1.2 & $\begin{array}{c}\text { Gram (+) } \\
\text { Gram (-) } \\
\text { Fungus }\end{array}$ & cationic & {$[27,53]$} \\
\hline \multicolumn{6}{|l|}{ Holothuroidea } \\
\hline Cucumaria frondosa & -- & $\sim 6$ & $\begin{array}{l}\text { Gram (-) } \\
\text { Gram (+) }\end{array}$ & n.d. & [23] \\
\hline Cucumaria echinata & -- & 4.2 & Gram (+) & -- & [54] \\
\hline \multirow{2}{*}{ Holothuria tubulosa } & Holothuroidin 1 & 1.4 & \multirow{2}{*}{$\begin{array}{l}\text { Gram (+) } \\
\text { Gram (-) }\end{array}$} & \multirow{2}{*}{ cationic } & \multirow{2}{*}[52]{} \\
\hline & Holothuroidin 2 & 1.5 & & & \\
\hline Apostichopus japonicus & $\mathrm{A} 3$ & 6.5 & $\begin{array}{l}\text { Gram (-) } \\
\text { Gram (+) }\end{array}$ & -- & {$[55]$} \\
\hline
\end{tabular}

Table 2: Cystein rich antimicrobial peptides.

microbial surfaces via electrostatic interactions, or may prevent biofilm maturation by killing the early surface colonizers, or by inhibiting quorum sensing $(\mathrm{QS})$, that is the communication system used by many bacteria to build a biofilm. QS is a system composed by small molecules that control collective behaviors, such as bioluminescence, virulence factor production, and biofilm formation [44-47].

As shown in Figure 1, biofilm-formation is generally initiated by the attachment of planktonic cells to a surface through weak van der Waals forces and the colonists are anchored tightly or irreversibly by pili (Figure 1a). To recruit other planktonic cells, the initial cells construct various adhesion sites and the matrix, an extracellular polymeric substance (EPS) (Figure 1b). EPS is composed of extracellular DNA, proteins, lipids, and polysaccharides with various configurations [48]. These components are very important targets for overcoming both biofilms and drug-resistant bacteria [49]. During colonization, some bacteria can communicate through a quorum sensing (QS) system. Subsequently, the grown or developed biofilm provides increased antibiotic-resistance to bacterial colonies through cell division and recruitment (Figure 1c). Later, the developed biofilms are dispersed and the bacteria move to other surfaces, (Figure 1d), where the biofilm formation process occurs again.

The mode of action of antibiotic peptides against biofilm is not fully understood, but it is believed that their major targets are cytoplasmic membrane and intracellular molecules $[14,50]$. It is also believed that it is very difficult for bacteria to develop resistance to antimicrobial peptides because most kill bacterial cells quickly through their actions on the entire cytoplasmic membrane or can act through complex mechanism [51].

Recently our research group has found novel peptides in P. lividus and in $H$. tubulosa, with a good activity in preventing biofilm formation of important pathogens involved in human and animal diseases, like staphylococcal or P. aeruginosa strains [27,52]. Sub-MIC concentrations of the $5-\mathrm{kDa}$ peptide fraction of the cytosol from coelomocytes of P.lividus were active to inhibit the formation of young ( 6 hours old) and mature (24 hours old) staphylococcal biofilm [27].
The synthetic peptides derived from AMP of $H$. tubulosa were able to inhibit biofilm formation against staphylococcal and Pseudomonas aeruginosa strains [53-55].

The anti-adhesion property of the tested peptides could be also very important against food transmitted pathogens and to contrast the biofilm mode of growth of various organisms involved in food spoilage.

In conclusion, the discovery of novel peptides in Echinoderms represents a good starting point to design new synthetic derivatives with modified chemical-physical properties, with the aim to improve their antimicrobial activity against pathogens and their pharmaceutical potential [46,47].

\section{References}

1. Castro MS, Fontes W (2005) Plant defense and antimicrobial peptides. Protein Pept Lett 12: 13-18.

2. Strominger JL (2009) Animal antimicrobial peptides: ancient players in innate immunity. J Immunol 182: 6633-6634.

3. Zasloff M (2002) Antimicrobial peptides of multicellular organisms. Nature 415 389-395

4. Riley MA, Chavan MA (2007) Bacteriocins. Ecology and Evolution.

5. Cotter PD, Hill C, Ross RP (2005) Bacterial lantibiotics: strategies to improve therapeutic potential. Curr Protein Pept Sci 6: 61-75.

6. RodrÃguez JM, MartÃnez MI, Kok J (2002) Pediocin PA-1, a wide-spectrum bacteriocin from lactic acid bacteria. Crit Rev Food Sci Nutr 42: 91-121.

7. O'Keefe BR (2001) Biologically active proteins from natural product extracts. J Nat Prod 64: 1373-1381.

8. da Rocha Pitta MG, da Rocha Pitta MG, Galdino SL (2010) Development of novel therapeutic drugs in humans from plant antimicrobial peptides. Curr Protein Pept Sci 11: 236-247.

9. Thomas S, Karnik S, Barai RS, Jayaraman VK, Idicula-Thomas S (2010) CAMP: a useful resource for research on antimicrobial peptides. Nucleic Acids Res 38: D774-780.

10. Brogden KA (2005) Antimicrobial peptides: pore formers or metabolic inhibitors in bacteria? Nat Rev Microbiol 3: 238-250

11. Yount NY, Bayer AS, Xiong YQ, Yeaman MR (2006) Advances in antimicrobial peptide immunobiology. Biopolymers 84: 435-458. 
12. Kamysz W, Okroj M, Łukasiak J (2003) Novel properties of antimicrobial peptides. Acta Biochim Pol 50: 461-469.

13. Hale JD, Hancock RE (2007) Alternative mechanisms of action of cationic antimicrobial peptides on bacteria. Expert Rev Anti Infect Ther 5: 951-959.

14. Nicolas $P$ (2009) Multifunctional host defense peptides: intracellular-targeting antimicrobial peptides. FEBS J 276: 6483-6496.

15. Bowdish DM, Davidson DJ, Lau YE, Lee K, Scott MG, et al. (2005) Impact of LL-37 on anti-infective immunity. J Leukoc Biol 77: 451-459.

16. Brown KL, Hancock RE (2006) Cationic host defense (antimicrobial) peptides. Curr Opin Immunol 18: 24-30.

17. Easton DM, Nijnik A, Mayer ML, Hancock RE (2009) Potential of immunomodulatory host defense peptides as novel anti-infectives. Trends Biotechnol 27: 582-590.

18. Lai Y, Gallo RL (2009) AMPed up immunity: how antimicrobial peptides have multiple roles in immune defense. Trends Immunol 30: 131-141.

19. Guaní-Guerra E, Santos-Mendoza T, Lugo-Reyes SO, Terán LM (2010) Antimicrobial peptides: general overview and clinical implications in human health and disease. Clin Immunol 135: 1-11

20. Hancock RE, Diamond G (2000) The role of cationic antimicrobial peptides in innate host defences. Trends Microbiol 8: 402-410.

21. Hancock RE, Brown KL, Mookherjee N (2006) Host defence peptides from invertebrates--emerging antimicrobial strategies. Immunobiology 211: 315-322.

22. Bals R, Wilson JM (2003) Cathelicidins--a family of multifunctional antimicrobia peptides. Cell Mol Life Sci 60: 711-720.

23. Beauregard KA, Truong NT, Zhang H, Lin W, Beck G (2001) The detection and isolation of a novel antimicrobial peptide from the echinoderm, Cucumaria frondosa. Adv Exp Med Biol 484: 55-62.

24. Haug T, Kjuul AK, Styrvold OB, Sandsdalen E, Olsen AM, et al. (2002) Antibacterial activity in Strongylocentrotus droebachiensis (Echinoidea) Cucumaria frondosa (Holothuroidea), and Asterias rubens (Asteroidea). J Invertebr Pathol 81: 94-102.

25. Ghanbari R, Ebrahimpour A, Abdul-Hamid A, Ismail A, Saari N (2012) Actinopyga lecanora Hydrolysates as Natural Antibacterial Agents. Int J Mol Sci 13: 16796-16811.

26. Aleshina GM, Mironchik EV, Malzeva AL, Klushevskaya ES, Krasnodembsky EG, et al. (2002) Antimicribial peptides from starfish Asterias rubens. Vestnik Sankt-Peterburgskogo Universiteta Ser 4: 135-137.

27. Schillaci D, Arizza V, Parrinello N, Di Stefano V, Fanara S, et al. (2010) Antimicrobial and antistaphylococcal biofilm activity from the sea urchin Paracentrotus lividus. J Appl Microbiol 108: 17-24.

28. Huff T, Müller CS, Otto AM, Netzker R, Hannappel E (2001) beta-Thymosins, small acidic peptides with multiple functions. Int J Biochem Cell Biol 33: 205220.

29. Tang YQ, Yeaman MR, Selsted ME (2002) Antimicrobial peptides from human platelets. Infect Immun 70: 6524-6533.

30. Safer D, Chowrashi PK (1997) Beta-thymosins from marine invertebrates: primary structure and interaction with actin. Cell Motil Cytoskeleton 38: 163171.

31. Saelee N, Noonin C, Nupan B, Junkunlo K, Phongdara A, et al. (2013) $\hat{I}^{2}$ thymosins and hemocyte homeostasis in a crustacean. PLoS One 8: e60974.

32. Zhang FX, Shao HL, Wang JX, Zhao XF (2011) $\hat{l}^{2}$-Thymosin is upregulated by the steroid hormone 20-hydroxyecdysone and microorganisms. Insect Mol Bio 20: $519-527$.

33. Li C, Haug T, Styrvold OB, Jørgensen TØ, Stensvåg K (2008) Strongylocins, novel antimicrobial peptides from the green sea urchin, Strongylocentrotus droebachiensis. Dev Comp Immunol 32: 1430-1440.

34. Selsted ME, Ouellette AJ (2005) Mammalian defensins in the antimicrobial immune response. Nat Immunol 6: 551-557.
35. Daher KA, Selsted ME, Lehrer RI (1986) Direct inactivation of viruses by human granulocyte defensins. J Virol 60: 1068-1074.

36. Mandal M, Nagaraj R (2002) Antibacterial activities and conformations of synthetic alpha-defensin HNP-1 and analogs with one, two and three disulfide bridges. J Pept Res 59: 95-104.

37. Li C, Blencke HM, Smith LC, Karp MT, Stensvåg K (2010) Two recombinant peptides, SpStrongylocins 1 and 2, from Strongylocentrotus purpuratus, show antimicrobial activity against Gram-positive and Gram-negative bacteria. Dev Comp Immunol 34: 286-292.

38. Li C, Haug T, Moe MK, Styrvold OB, StensvÃ¥g K (2010) Centrocins: isolation and characterization of novel dimeric antimicrobial peptides from the green sea urchin, Strongylocentrotus droebachiensis. Dev Comp Immunol 34: 959-968.

39. Bjorn C, HÃkansson J, Myhrman E, Sjostrand V, Haug T, et al. (2012) Antiinfectious and anti-inflammatory effects of peptide fragments sequentially derived from the antimicrobial peptide centrocin 1 isolated from the green sea urchin, Strongylocentrotus droebachiensis. AMB Express 2: 67.

40. Wilson M (2001) Bacterial biofilms and human disease. Sci Prog 84: 235-254.

41. Parsek MR, Singh PK (2003) Bacterial biofilms: an emerging link to disease pathogenesis. Annu Rev Microbiol 57: 677-701.

42. Archer NK, Mazaitis MJ, Costerton JW, Leid JG, Powers ME, et al. (2011) Staphylococcus aureus biofilms: properties, regulation, and roles in human disease. Virulence 2: 445-459.

43. Obst U, Schwartz T, Volkmann H (2006) Antibiotic resistant pathogenic bacteria and their resistance genes in bacterial biofilms. Int J Artif Organs 29: 387-394.

44. Horswill AR, Stoodley P, Stewart PS, Parsek MR (2007) The effect of the chemical, biological, and physical environment on quorum sensing in structured microbial communities. Anal Bioanal Chem 387: 371-380.

45. Spoering AL, Gilmore MS (2006) Quorum sensing and DNA release in bacterial biofilms. Curr Opin Microbiol 9: 133-137.

46. Brogden NK, Brogden KA (2011) Will new generations of modified antimicrobial peptides improve their potential as pharmaceuticals? Int $\mathrm{J}$ Antimicrob Agents 38: $217-225$.

47. Huang Y, Huang J, Chen Y (2010) Alpha-helical cationic antimicrobial peptides: relationships of structure and function. Protein Cell 1: 143-152.

48. Hall-Stoodley L, Stoodley P (2009) Evolving concepts in biofilm infections. Cell Microbiol 11: 1034-1043.

49. Landini P, Antoniani D, Burgess JG, Nijland R (2010) Molecular mechanisms of compounds affecting bacterial biofilm formation and dispersal. Appl Microbio Biotechnol 86: 813-823.

50. Pieters RJ, Arnusch CJ, Breukink E (2009) Membrane permeabilization by multivalent anti-microbial peptides. Protein Pept Lett 16: 736-742.

51. Chan DI, Prenner EJ, Vogel HJ (2006) Tryptophan- and arginine-rich antimicrobial peptides: structures and mechanisms of action. Biochim Biophys Acta 1758: 1184-1202

52. Schillaci D, et al. (2013) Immune mediators of sea-cucumber Holothuria tubulosa (Echinodermata) as source of novel antimicrobial and antistaphylococcal biofilm agents. AMB Express.

53. Schillaci D, Vitale M, Cusimano MG, Arizza V (2012) Fragments of $\hat{l}^{2}$-thymosin from the sea urchin Paracentrotus lividus as potential antimicrobial peptides against staphylococcal biofilms. Ann N Y Acad Sci 1270: 79-85.

54. Hisamatsu K, Tsuda N, Goda S, Hatakeyama T (2008) Characterization of the \{alpha\}-helix region in domain 3 of the haemolytic lectin CEL-III: implications for self-oligomerization and haemolytic processes. J Biochem 143: 79-86.

55. Jian Tan, Zonghong Liu, Mark Perfetto, Lulu Han, Quying Li, et al. (2012) Isolation and purification of the peptides from Apostichopus japonicus and evaluation of its antibacterial and antitumor activities. African Journal of Microbiology Research 6: 7139-7146

Citation: Schillaci D, Arizza V (2013) Echinoderm Antimicrobial Peptides to Contrast Human Pathogens. Nat Prod Chem Res 1: 109. doi:10.4172 npcr.1000109 